\title{
The Analysis of Death of a Salesman From the Perspective of Modern Tragedy
}

\author{
WEI Qingxia \\ University of Shanghai for Science and Technology, Shanghai, China
}

\begin{abstract}
Arthur Miller is a distinguished modern playwright who pays lots of attention to social issues. As one of his masterpieces, Death of a Salesman depicts that the protagonist fails to achieve his American dream and finally chooses to die. This paper analyzes the tragic flaw and the tragic victory in the protagonist as a salesman as well as a father, aiming to explore how the elements of modern tragedy are embodied in the common man.

Keywords: Death of a Salesman, American dream, modern tragedy
\end{abstract}

\section{Introduction}

Tragedy has a distant origin of Greek tragedy, which normally focuses on the downfall of noble men. According to Aristotle, the tragic hero is supposed to be someone with "high fame and flourishing prosperity" (Golden, 1968, p. 22). With the advancement of industrialization, middle class has gradually become an integral group in society. Accordingly, the concern of tragedy undergoes a significant shift to ordinary men and therefore arises the modern tragedy. As Arthur Miller points out, the common man is as apt a subject for tragedy in its highest sense as kings are (Martin, 1978, p. 3). Death of a Salesman is a typical representative of modern tragedy, with the protagonist being an ordinary salesman. The tragic flaw of the main character lies in his false belief in American dream. Yet he achieves tragic victory by the virtue of trying to maintain his dignity as a salesman and his identity of the fatherhood.

\section{Willy Loman as a Salesman}

As a salesman, Willy fails to recognize himself due to his false belief in American dream and therefore chooses a way that actually does not suit him. His father is an extraordinary craftsman who is equipped with great skills in inventing flutes and makes a living by selling them across the country. And his brother enters into the jungle at a young age and makes a big fortune. When it comes to Willy, he has an inclination to the nature just as his father and brother, which can be seen from his complaints about the urban life. He complains that "the street is lined with cars. There's not a breath of fresh air in the neighborhood" (Liu \& Zhu, 2014, p. 506). On the other hand, Willy has a craving for the huge success in the city as a salesman. For example, he entertains a worship for Dave Singleman who is an 84 years old salesman and makes his sales just by calling his customers even without leaving his hotel room. Attracted by the seemingly easy success, Willy chooses to struggle in the concrete city despite his hatred for the urban life. However, this career choice is against his

WEI Qingxia, postgraduate, Executive Director of the Academic Union, Department of Foreign Language, University of Shanghai for Science and Technology, Shanghai, China. 
nature and thus inevitably causes his breakdown. At the beginning of the play, he says that "I am tired to the death. I couldn't make it. I just couldn't make it” (Liu \& Zhu, 2014, p. 502). From his remarks, it can be clearly seen that he is exhausted physically and spiritually after fruitless struggles. He persuades himself that he is also doing hunting in Brooklyn just in a different form from that of his father and brother. The self-delusion indicates that he regards his choice as a balanced compromise and consciously justifies the option he has chosen (Shi, 2012, p. 99). Yet actually his instinctual admiration for nature and his longing for success in city constitute a vast contradiction and this contradiction in his internal world results in his downfall.

Willy adheres to the belief in traditional American dream, which makes him incompatible with the new business world. Traditionally, American dream is based on the principles of freedom and equality. According to the Declaration of Independence, everyone is endowed with the inalienable right to pursue happiness (Ke, 2010, p. 111). Nevertheless, as the industrialization develops, the value of American dream has deviated from its original connotation and been degraded. As Willy claims, "there was respect, and comradeship, and gratitude in it. Today, it's all cut and dried" (Liu \& Zhu, 2014, p. 559). Although he has contributed nearly all his life to the company, he is mercilessly fired when he is old and less productive than before. It is obvious that the profit is the only concern of the company and the basic care for men is abandoned. Encountering this situation, Willy makes the accusation that "You can't eat the orange and throw the peel away-a man is not a piece of fruit" (Liu \& Zhu, 2014, p. 559). Clearly, he fails to be aware of the cruel code of new business world. The lack of Willy's awareness can be also seen from Charley's remarks, “you named him Howard, but you can't sell that. The only thing you got in this world is what you can sell. And the funny thing is that you're a salesman, and you don't know that" (Liu \& Zhu, 2014, p. 572). To some degree, his adherence to the false belief is the main reason for his tragic failure. However, his response to the failure enables him to maintain his dignity and thus transcend the failure. Even though he has to borrow fifty dollars every week to support his family, Willy rejects the job offered by Charley for he thinks it is out of sympathy. This action is kind of stubborn but it is the uncompromising stubbornness that highlights the tragic sense in the ordinary salesman.

\section{Willy Loman as a Father}

As a father, Willy endeavors to transfer his false belief to his sons through educating, thus further strengthening the tragic effect. This can be firstly demonstrated by the fact that he encourages the unlawful behaviors of his son. When Biff brings a ball from the locker-room, Willy does not criticize him but defends him by saying "he's gotta practice with a regulation ball, doesn't he? Coach will probably congratulate you on your initiative" (Liu \& Zhu, 2014, p. 517). Similarly, Willy regards Biff's behavior of stealing lumber from a local construction site as the embodiment of fearlessness, which he considers as a necessary personality to be successful. His tolerance of his son's misdeeds prevents them from realizing their mistakes, which has an adverse impact on their later life. For instance, when Biff turns to his old boss for help, he unconsciously takes the boss's pen away. Besides, Willy instills his distorted understanding of the approach to success into his son. He tells his sons that

Bernald can get the best marks in school, y' understand but when he gets out in the business world, y' understand, you are going to be five times ahead of him. That's why I thank Almighty God you're built like Adonises. Because the man who makes an appearance in the business world, the man who creates personal interest, is the man who gets ahead. Be liked and you will never want. (Liu \& Zhu, 2014, p. 520) 
He despises Bernald for his hard work and praises his sons for their appearance and popularity. Ironically, it turns out that Bernald finds a decent job in the Supreme Court while his sons achieve nothing. Billy says angrily that "I never got anywhere because you blew me so full of hot air I could never stand taking orders from anybody! That's whose fault it is" (Liu \& Zhu, 2014, 601). It is reasonable to say that Willy's improper education should be responsible for his son's failure.

Willy's final choice to die of his own accord reinforces the tragic effect to the utmost. He chooses to commit suicide because he believes the insurance money offered after his death can help his sons to achieve their success and his unfinished dream. Also, he hopes he can re-establish his successful image and thus regain the respect from his sons. Willy describes that "Ben, that funeral will be massive...that boy will be thunder struck, Ben, because he never realized-I am known" (Liu \& Zhu, 2014, p. 596). On the one hand, his self-deception of the magnificent scene and his illusion of American dream evoke the tragic feeling in us. He treats his life as the last asset and sells himself as a piece of commodity. It seems that he holds fast to the cause of selling until the last moment of his life and becomes a victim of the society where the consumerism is prevalent. On the other hand, his attempts to maintain his dignity elevate him from being commonplace to a noble status. As Arthur Miller points out, the flaw is really nothing but his inherent unwillingness to remain passive in the face of what he conceives to be a challenge to his dignity (Miller, 1958, p. 30). Whether the insurance money can be given or the dream can be achieved, he is at least making an active response to his situation rather than accepting his fate passively. And according to Arthur Miller, a man's death is an essentially terrifying thing, but the ultimate negative can be an assertion of bravery and serves to separate the death of man from the death of animals (Miller, 1958, p. 31). Therefore, to some degree, he has achieved the tragic victory by willingly laying down his life.

\section{Conclusion}

As has been demonstrated, Willy Loman's blind faith in the American dream is his fatal flaw and the root of his tragedy. There exists an interdependent relationship between men and society, which exerts influence on each other. The consumerism prevailing in the society has distorted his belief and resulted in his downfall. Although Willy is just a common man, his willingness to sacrifice for his cause elevates him to a heroic status and constitutes his victory. Moreover, in this ordinary man, the general audience is likely to find something similar to them and contemplates about their situation, which is exactly the essence of the literary work. 


\section{References}

Golden, L. (1968). Aristotle poetics: A translation and commentary for students of literature. New York: Prentice.

Ke, J. H. (2010). On the Ethical Conflicts in The Death of a Salesman. Foreign Literature Studies, (4), 110-116.

Liu, H. P., \& Zhu, X. F. (2014). Anglo-American Drama: Works and Reviews. Shanghai: Shanghai Foreign Language Education Press.

Martin, R. A. (1978). The theater essays of Arthur Miller. New York: Viking Penguin Inc.

Miller, A. (1958). The tragedy and the common man: Introduction to collected plays. New York and London: Viking Penguin Inc. Shi, Q. J. (2012). Natural Imagination in The Death of a Salesman - Also on Arthur Miller's View of Nature. Journal of PLA University of Foreign Languages, (2), 97-100. 